\title{
KESESUAIAN LAHAN TANAMAN JAGUNG DI KABUPATEN MINAHASA SELATAN
}

\author{
Johannes E. X. Rogi1), Johan A. Rombang 2), Josephus I. Kalangi 3), \\ dan Malsupri Taher ${ }^{4)}$ \\ ${ }^{1)}$ dan ${ }^{3)}$ Lab. Modeling Ekosistem Jurusan Budidaya Pertanian, Fakultas Pertanian UNSRAT \\ 2) Staf Jurusan Tanah, Fakultas Pertanian UNSRAT \\ 4) Mahasiswa Jurusan Budidaya Pertanian, Fakultas Pertanian UNSRAT
}

\begin{abstract}
Rogi, J.E.X. et. al. 2007. The Suistability Land for Corn in the South Minahasa District. Eugenia 13 (3) : 320-326.

Based on agri-climate and market prospective, corn is a potential comodity in the South-Minahasa District. From 215.000 ha of South-Minahasa District area, it has 18.437 ha harvest-area and in 2006 produced 52.747 tonnes corn. The above data showed that this district has a possibility to extend the corn planting area in suitable area. To find this suistability area for corn, a spatial data was composed based on soil and climate data using Geographic Information Systemm (GIS). Soil data consisted of texture, pH, Corganic, and cation exchange capacity (CEC), whereas climate data consisted of rainfall and air temperature. Spatial data in the form of land suitability map for corn in the South-Minahasa District was analysed using ArcViewer 3.2. software.
\end{abstract}

Keywords: Harvest area, soil and climate, spatial data, GIS, ArcViewer 3.2

\section{PENDAHULUAN}

Untuk menentukan apakah suatu wilayah cocok untuk dikembangkan suatu tanaman maka usaha yang diperlukan tidak hanya berdasarkan atas teknik budidaya yang baik melainkan disertai dengan beberapa upaya non teknis seperti pengembangan sektor pertanian yang menggunakan teknologi informasi. Upaya pengembangan sektor pertanian yang menggunakan teknologi informasi sudah banyak berhasil diterapkan di Indonesia. Sistem Informasi Geografis (SIG) untuk menentukan pewilayahan komoditi pertanian, pendugaan produksi tanaman dengan menganalisis fluktuasi iklim, penyu- sunan basis data iklim dan tanah untuk menduga pengembangan suatu tanaman adalah contoh dari penggunaan teknologi informasi, dengan suatu harapan informasi yang diperoleh dapat digunakan sebaik mungkin untuk pengembangan di sektor pertanian. Informasi yang dimaksudkan merupakan informasi yang mendasar dan akurat, misalnya dapat berupa data mengenai kondisi alam suatu daerah yaitu kondisi iklim dan tanah. Diharapkan dengan pengetahuan akan data tersebut pengembangan tanaman jagung di Kabupaten Minahasa Selatan dapat berjalan dengan baik.

Data yang terdiri dari peta kesesuaian lahan dan data nominal ini yang 
dimaksudkan dengan data spasial. Dengan kata lain data spasial merupakan sekelompok data yang terdiri dari peta geografi suatu wilayah dan data nominal untuk menerangkan peta tersebut. Sehingga dengan adanya data spasial tersebut, dapat memberikan informasi kepada pemerintah, pengusaha serta petani dalam penentuan kesesuaian lahan. Kesesuaian lahan (land suitainability) adalah kecocokan suatu lahan untuk penggunaan tertentu, sebagai contoh lahan sesuai untuk pertanian tanaman semusim. Lebih spesifik lagi kesesuaian lahan tersebut ditinjau dari sifat-sifat fisik lingkungannya, yang terdiri dari iklim, tanah, topografi dan hidrologi sesuai untuk usaha tani atau komoditas tertentu yang produktif. Kesesuaian lahan juga merupakan kesesuaian dari sebidang lahan untuk tujuan penggunaan komoditi spesifik misalnya jagung. Penggunaan dan pemanfaatan sumber daya lahan yang optimal sesuai dengan daya dukungnya akan dapat dilakukan apabila tersedia informasi mengenai kesesuaian lahan di masing-masing wilayah yang bersangkutan. Untuk evaluasi lahan diperlukan tersedianya data iklim dan data tanah di samping datadata yang lain (Djaenudin, Darmawan, Subagio, Hidayat 2000).

Suatu informasi yang cepat dan aktual sangat diperlukan terutama bagi para pengambil keputusan maupun masyarakat pada umumnya. Informasi dapat menjadi suatu peluang, mendatangkan suatu keuntungan, bahkan dapat menjadi suatu ancaman tergantung kepada siapa informasi ditujukan dan yang mengintepretasikan informasi tersebut. Wilayah Indonesia yang luas dan kaya dengan produk pertaniannya, memerlukan suatu sistem informasi yang dapat membantu kebutuhan informasi tentang komoditi perta- nian unggulan yang ada pada suatu wilayah di nusantara ini. Informasi kecocokan suatu wilayah untuk tanaman bernilai ekonomi tinggi sangat diperlukan bagi para penanam modal pertanian informasi pusat produksi tanaman, informasi pasar untuk penjualan komoditi, dan sebagainya sangat diperlukan bagi para pengusaha pertanian (Rogi, Rombang, Kalangi 2005).

Penelitian ini bertujuan menyusun data spasial berdasarkan data ilkim dan tanah untuk pengembangan tanaman jagung di Kabupaten Minahasa Selatan dan Menentukan daerah pengembangan tanaman jagung di Kabupaten Minahasa Selatan.

\section{METODE PENELITIAN}

\section{Waktu dan Tempat Penelitian}

Penelitian ini dilakukan selama 3 (tiga) bulan yaitu pada bulan Oktober sampai Desember 2006. Lokasi penelitian seluruh wilayah Kabupaten Minahasa Selatan yang terdiri dari 15 kecamatan (Jumlah kecamatan tahun 2005) yaitu : Belang, Kumelembuai, Motoling, Modoinding, Ranoyapo, Ratahan, Ratatotok, Sinonsayang, Tareran, Tenga, Tombasian, Tombatu, Tompaso Baru, Toluaan, Tumpaan. Analisis data lapangan dilakukan di Laboratorium Modeling Ekosistem Jurusan Budidaya Pertanian dan Laboratorium Tanah dan Tanaman SEAMEO BIOTROP IPB Bogor.

\section{Bahan dan Alat}

Alat yang digunakan antara lain Global Position System (GPS), cangkul, sekop, meteran, alumunium foil, kantong plastik, parang, perangkat lunak komputer yaitu Sistem Basis Data Klimatologi (SDBK) Versi 1.1 Seri Sulawesi Utara 
dan Program Arcview GIS 3.2. dan 1 (satu) unit PC (Personal Computer).

Penelitian dilaksanakan dengan metode survei pengambilan sampel. Dari survey ini akan diperoleh data Iklim yang meliputi curah hujan dan suhu udara rata-rata, data tanah yang meliputi tekstur, $\mathrm{pH}$ tanah, C-organik dan KTK. Untuk data iklim menggunakan Program Sistem Basis Data Klimatologi (SDBK) versi 1.1 Seri Sulawesi Utara. Program dijalankan dengan menginput nilai lintang dan bujur, dan akan menghasilkan output berupa data iklim antara lain yaitu data curah hujan dan suhu udara. Sedangkan untuk data tanah dianalisis di Laboratorium Tanah dan Tanaman SEAMEO BIOTROP IPB Bogor. Data spasial berupa peta kesesuaian lahan tanaman jagung di Kabupaten Minahasa Selatan di analisis menggunakan Program turunan Sistem Informasi Geografis yaitu Arcview versi 3.2.

\section{Prosedur Kerja Survey}

Pengambilan titik koordinat pada lokasi penelitian yang ada di wilayah Kabupaten Minahasa Selatan dengan menggunakan GPS (Global Position System). Pengambilan sampel tanah pada lokasi penelitian yang ada di wilayah Kabupaten Minahasa Selatan.

\section{Analisis Data}

1. Data iklim dianalisis dengan menggunakan Program Sistem Basis Data Klimatologi (SDBK) versi 1.1 Seri Sulawesi Utara. Data koordinat yang telah diperoleh melelui survey di input kedalam program yang kemudian akan menghasilkan output berupa tabel data suhu udara per hari selama satu tahun dan data curah hujan perbulan selama satu tahun.

2. Analisis data tanah dilakukan di laboratorium Tanah dan Tanaman SEAMEO BIOTROP IPB Bogor.

\section{Overlay Data}

1. Overlay data iklim, pada perangkat komputer, buka Arc View, selanjutnya Arc View akan menanyakan membuat project baru atau memanggil project yang sudah ada. Pembuatan project baru dilakukan dengan memanggil opsi With $A$ New View, setelah program dibuka diinput peta dasar kabupaten Minahasa Selatan. Kemudian diperoleh peta kesesuaian iklim tanaman jagung.

2. Overlay data tanah, pada perangkat komputer, buka Arc View, selanjutnya Arc View akan menanyakan membuat project baru atau memanggil project yang sudah ada. Pembuatan project baru dilakukan dengan memanggil opsi With $A$ New View, setelah program dibuka diinput peta dasar kabupaten Minahasa Selatan. Kemudian diperoleh peta kesesuaian tanah tanaman jagung.

3. Overlay peta kesesuaian iklim dan tanah untuk mendapatkan peta kesesuaian agroekologi tanaman jagung.

\section{HASIL DAN PEMBAHASAN}

Hasil penelitian menunjukkan bahwa wilayah Minahasa Selatan memiliki jenis tekstur tanah yang bervariasi, dari tanah yang bertekstur halus sampai pada tanah yang bertekstur kasar. Pengamatan di lapangan menunujukkan bahwa Ke- 
camatan Tombatu, Toluaan, Tombasian dan Ratahan memiliki tekstur tanah yang kasar, sehingga daerah-daerah ini tidak dapat direkomendasikan untuk pengembangan tanaman jagung karena tanaman jagung membutuhkan tekstur tanah yang halus. Drainase yang dijumpai di Kabupaten Minahasa Selatan pada umumnya baik untuk pertumbuhan tanaman jagung, karena drainase yang ada berkisar dari baik sampai terhambat. Solum tanah di wilayah Kabupaten Minahasa Selatan umumnya lebih dari satu (1) meter. Kedalaman efektif yang kurang dari $1 \mathrm{~m}$ dapat dijumpai pada tanah-tanah di Kecamatan Belang, Ratatotok, dan Modoinding.

pH tanah-tanah di wilayah Kabupaten Minahasa Selatan berada pada kisaran 5,5-7. Hal ini menunjukkan bahwa tanah-tanah di wilayah Kabupaten Minahasa Selatan tidak bermasalah dari segi kemasaman, selain $\mathrm{pH}$ tanah, kadar Corganik yang terdapat di wilayah Kabupaten Minahasa Selatan berada pada tingkat yang rendah. Kapasitas tukar kation tanah-tanah di wilayah Kabupaten Minahasa Selatan berada pada kisaran rendah sampai tinggi, alkalinitas berada pada tingkat yang rendah sehingga tidak akan menimbulkan permasalahan bagi tanaman. Kecamatan-kecamatan yang memiliki salinitas yang relatif tinggi yaitu Tumpaan, Tombatu, Tompaso Baru, Toluaan, Tombasian.

Ketinggian tempat bervariasi dari 12 - 1114 m dpl, karena Daerah Minsel terdiri dari daerah pesisir dan pegunungan. Sebagian besar topografi Kab. Minsel adalah bergunung, sehingga ba- nyak daerah yang memiliki kelerengan yang curam.

Berikut diuraikan data spasial beserta dengan faktor-faktor pembatas untuk tiap tingkat kesesuaian lahan untuk tanaman jagung di Kabupaten Minahasa Selatan.

Berdasarkan Tabel 1, luas lahan yang tergolong dalam kelas kesesuaian lahan sangat sesuai (S1) untuk tanaman jagung di Kabupaten Minahasa Selatan sebesar 794,46 ha atau $0,37 \%$ dari seluruh penggunaan lahan di Kabupaten Minahasa Selatan, 22,78 ha berada di Kecamatan Ranoyapo dan 771,68 ha berada di wilayah Kecamatan Tompaso Baru. Dari seluruh penggunaan lahan di Kabupaten Minahasa Selatan (214.252, 92 ha) terdapat 8061 ha atau 3,71\% lahan yang tergolong dalam kelas kesesuaian lahan cukup sesuai (S2) untuk tanaman jagung yang terdapat di beberapa kecamatan yaitu, Belang (18,27 \%), Motoling $(2,32 \%)$, Ranoyapo (4,72 \%), Ratatotok $(6,28 \%)$, Sinonsayang $(3,86 \%)$, Tareran $(10,55 \%)$, Tenga $(12,51 \%)$, Tombasian $(1,20 \%)$, Tompaso Baru $(27,74 \%)$, Tumpaan (12,55 \%).

Luas lahan dari kelas kesesuaian lahan sesuai marginal (S3) untuk tanaman jagung di Kabupaten Minahasa Selatan sebesar 14573,14 ha atau 5,87 \% dari keseluruhan penggunaan lahan di Kabupaten Minahasa Selatan. Sedangkan luas lahan yang tidak sesuai untuk tanaman jagung sebesar 190823,49 ha atau $89,06 \%$ dari seluruh penggunaan lahan yang ada di Kabupaten Minahasa Selatan. 
Tabel 1. Luas Kesesuaian Lahan Tanaman Jagung di Kabupaten Minahasa Selatan (Land Suitability Area for Corn in the South Minahasa District)

\begin{tabular}{|c|l|c|c|c|c|r|r|r|c|}
\hline \multirow{2}{*}{ No } & \multirow{2}{*}{ Kecamatan } & \multicolumn{7}{|c|}{ Kelas Keseuaian Lahan } \\
\cline { 3 - 10 } & & $\begin{array}{c}\text { Luas } \\
\text { (ha) }\end{array}$ & $\%$ & Luas (ha) & $\%$ & $\begin{array}{c}\text { Luas } \\
\text { (ha) }\end{array}$ & $\%$ & Luas (ha) & $\%$ \\
\hline 1 & Belang & 0 & 0 & 1472,66 & 0,68 & 0 & 0 & 9372,41 & 4,37 \\
\hline 2 & Kumelembuai & 0 & 0 & 0 & & 1010,24 & 0,47 & 4329,54 & 2,02 \\
\hline 3 & Modoinding & 0 & 0 & 0 & & 801,82 & 0,37 & 4089,57 & 1,91 \\
\hline 4 & Motoling & 0 & 0 & 187,43 & 0,08 & 1093,83 & 0,51 & 9725,91 & 4,54 \\
\hline 5 & Ranoyapo & 22,78 & 0,01 & 380,66 & 0,17 & 1104,73 & 0,51 & 6811,46 & 3,18 \\
\hline 6 & Ratahan & 0 & 0 & 0 & & 368,61 & 0,16 & 17804,13 & 8,31 \\
\hline 7 & Ratatotok & 0 & 0 & 506,37 & 0,23 & 478,58 & 0,22 & 8520,53 & 3,98 \\
\hline 8 & Sinonsayang & 0 & 0 & 311,29 & 0,14 & 615,74 & 0,29 & 14126,63 & 6,59 \\
\hline 9 & Tareran & 0 & 0 & 850,67 & 0,39 & 0 & 0 & 7935,89 & 3,70 \\
\hline 10 & Tenga & 0 & 0 & $1.008,72$ & 0,47 & 2144,01 & 1,00 & 18502,60 & 8,64 \\
\hline 11 & Tombasian & 0 & 0 & 96,51 & 0,04 & 495,48 & 0,23 & 22751,68 & 10,62 \\
\hline 12 & Tombatu & 0 & 0 & 0 & & 106,35 & 0,05 & 12653,97 & 5,91 \\
\hline 13 & Tompaso Baru & 771,68 & 0,36 & 2236,00 & 1,04 & 413,57 & 0,19 & 23907,22 & 11,16 \\
\hline 14 & Toluaan & 0 & 0 & 0 & & 237,64 & 0,11 & 16401,78 & 7,66 \\
\hline 15 & Tumpaan & 0 & 0 & 1011,52 & 0,47 & 3776,61 & 1,76 & 13890,20 & 6,48 \\
\hline & TOTAL & 794,46 & 0,37 & 8061,83 & 3,71 & 14573,14 & 5,87 & 190823,49 & 89,06 \\
\hline
\end{tabular}

Sifat fisik tanah merupakan sifat yang sangat sulit dirubah. Oleh karena itu, tanah-tanah yang memiliki variabel pembatas sifat fisik tanah, umumnya sulit dinaikkan kelasnya menjadi kelas yang lebih sesuai. Untuk mengatasi masalah ini, sebaiknya daerah yang sifat fisik tanahnya tidak sesuai untuk tanaman jagung diganti penggunaan lahannya untuk komoditas lain yang lebih sesuai.

Berbeda dengan sifak fisik tanah, sifat kimia tanah masih dapat diperbaiki kualitasnya. Oleh karena itu, tanah-tanah yang memiliki variabel pembatas sifat kimia untuk penggunaan lahan tanaman jagung masih dapat ditingkatkan kelas kesesuaiannya melalui penerapan teknologi tertentu, tergantung variabel pembatasnya. Contohnya masalah salinitas, salinitas yang tinggi dapat diatasi dengan pencucian garam-garam dengan irigasi. Air yang tersedia cukup dapat mengurangi kadar garam dalam tanah, pemakaian jumlah air yang diperlukan bergantung pada berapa besar penurunan kadar garam yang diinginkan.

Iklim merupakan salah satu komponen lahan dan faktor yang sangat menentukan kemampuan produktivitas lahan bagi pengembangan suatu komoditas pertanian. Perilaku iklim ini sulit diramal atau tidak dapat direkayasa dan dimanipulasi. Suhu udara merupakan faktor lingkungan yang penting pengaruhnya 
pada pertumbuhan tanaman dan berperan hampir pada semua proses pertumbuhan. Suhu udara merupakan faktor penting dalam menentukan tempat dan waktu penanaman yang cocok, bahkan suhu udara dapat juga sebagai faktor penentu dari pusat-pusat produksi tanaman, misalnya kentang di daerah bersuhu rendah, sedangkan padi di daerah bersuhu lebih tinggi (Bayong 1992).

Curah hujan memegang peran penting dalam pertumbuhan dan produksi tanaman. Hal ini dihubungkan dengan ketersediaan air dalam tanah. Air sebagai pengangkut hara dari tanah ke akar dan diteruskan ke bagian-bagian lain dalam jaringan tanaman. Fotosintesis akan menurun jika $30 \%$ kandungan air dalam daun hilang, kemudian proses fotosintesis akan terhenti jika kehilangan air mencapai 60 \% (Griffiths 1976). Curah hujan yang sangat rendah tidak merupakan pembatas selama ada fasilitas irigasi. Namun, ada komoditi tertentu yang tidak hanya memerlukan keadaan tanah yang selalu lembab, tetapi juga memerlukan adanya curah hujan untuk proses atau pertumbuhan generatif agar mampu berproduksi. Oleh karena itu, dalam memilih lokasi untuk pengembangan suatu komoditi, faktor iklim harus menjadi bahan pertimbangan pertama, baru kemudian faktor lainnya yang berpengaruh terhadap komoditi yang bersangkutan.

Data dan informasi tentang keadaan iklim sangat diperlukan sebagai seleksi awal dalam identifikasi potensi lahan dan penetapan strategi pengembangan komoditi pertanian di suatu daerah. Peluang untuk memanipulasi data iklim sangat kecil dan sulit diduga. Oleh karena itu, untuk pewilayahan komoditi pertanian, penyesuaian budidaya dan paket teknologi pertanian dengan kondisi iklim se- tempat merupakan suatu pendekatan yang paling tepat (Las et al. 2000).

\section{KESIMPULAN}

Kesesuaian lahan tanaman jagung di Kabupaten Minahasa Selatan untuk sangat sesuai $(\mathrm{SI})$ terdapat di dua wilayah Kecamatan yaitu, Kecamatan Tompaso Baru dan Kecamatan Ranoyapo. Kelas kesesuaian lahan cukup sesuai (S2) 8061.83 ha atau 3,76\% dari total luas wilayah Kabupaten Minahasa Selatan, 14573,14 ha atau $6,80 \%$ lahan sesuai marginal (S3) dan 190823,49 ha atau $89,06 \%$ lahan yang tidak sesuai $(\mathrm{N})$ dari seluruh penggunaan lahan yang ada di Kabupaten Minahasa Selatan.

Dengan adanya perlakuan irigasi yang baik, maka faktor salinitas tidak menjadi masalah yang berarti sehingga luas kesesuaian lahan berubah menjadi 6782,18 ha $(3,16 \%)$ untuk kelas lahan sangat sesuai, 5599,56 ha $(2,61 \%)$ untuk kelas lahan cukup sesuai dan 10038,97 ha $(4,68 \%)$ untuk kelas lahan sesuai marginal. Kecamatan-kecamatan yang wilayahnya terdapat kelas lahan yang sangat sesuai untuk tanaman jagung yaitu Tumpaan, Ratatotok, Tareran, Tombasian, Tombatu, Tompaso Baru, Toluaan dan Ranoyapo. Kecamatan-kecamatan ini dapat direkomendasikan sebagai daerah-daerah pengembangan tanaman jagung.

\section{UCAPAN TERIMA KASIH}
1. Pemerintah Kabupaten Minahasa Selatan
2. Lembaga Penelitian Universitas Sam Ratulangi
3. Laboratorium Modeling Ekosistem
4. Laboratorium SEAMEO-BIOTROP 


\section{DAFTAR PUSTAKA}

Bayong, T. H. K 1992. Klimatologi Terapan. PenerbitPionir Jaya. Bandung.

Djaenudin, D. Darmawan. H, H. Subagio, A. Hidayat. 2000. Kriteria Kesesuaian Lahan Untuk Komoditas Pertanian. Pusat Penelitian Tanah dan Agroklimat; Badan Penelitian dan Penembangan Pertanian. Versi 3. Bogor.

Griffths, J. K. 1976. Applied Climatology. McGraw - Hill Book Company, Inc. New York.
Las, I., G. Irianto, D. Syarifudin, dan L. Istiqlal Amien. 2000. Pendekatan Agroklimat Dalam Membangun Pertanian Tangguh; Status, Potensi, Kendala, dan Teknologi Analisis Iklim untuk Mengurangi Risiko Pertanian. Prosiding Seminar Nasional Sumber Daya Tanah, Iklim, dan Pupuk. Lido-Bogor, 6-8 Desember. Hal. 55 - 94.

Rogi. J., Rombang, J., Kalangi, J.I. 2005. Pewilayahan Komoditi Pertanian Di Kabupaten Minahasa Selatan. Kerjasama Lembaga Penelitian UNSRAT dengan BAPPEDA Kabupaten Minahasa Selatan. Manado. 